\title{
ANALISIS AKUNTANSI UNTUK PERSEDIAAN OBAT GENERIK BERDASARKAN PADA PSAP NO. 05 DI RSUD ABDOEL WAHAB SJAHRANIE SAMARINDA
}

\author{
Ros Nirwana \\ Elfreda Aplonia Lau \\ Umi Kulsum
}

\begin{abstract}
University of 17 Agustus 1945 Samarinda
Jl. Ir. H. Juanda No. 80, 75124, Indonesia elfredalau9@gmail.com
\end{abstract}

\begin{abstract}
This reseach aim to compare recording and drugs inventory especially characterized generic drug by the largest transaction and drugs that often out of stock. Generic drugs consist of five types of generic injection and five types of tablets, spesifically $\mathrm{NaCl} \mathrm{0,9 \%} 500$ Ml Inj, Ranitidin Inj, Dexamethasone $5 \mathrm{Ml}$ Inj, Cefotaxime $1 \mathrm{~g}$ Inj, Gentamicin $80 \mathrm{Mg}$ Inj, Amoxicillin $500 \mathrm{Mg}$, Antasida Doen, Dexamethasone 0,5 Mg, Chlorpeniramin, and Lansoprazol from January 1st to December 31st 2018 at RSUD Abdoel Wahab Sjahrani Samarinda on Palang Merah street Samarinda Indonesia, according to recording and aassessment stock of generic drugs river to PSAP No 05 of 2010.

Methods in this comparison were Perpetual Method and First In First Out(FIFO) Method based on PSAP No. 05 of 2010. The results of this research were the recording and assessment of generic drug supplies at Abdoel Wahab Sjahranie Samarinda General Hospital not in accordance with PSAP No. 05 of 2010
\end{abstract}

Keywords: Recording, Assessment, Inventory, Perpetual, FIFO, and PSAP No. 05 of 2010

\section{PENDAHULUAN}

Keberhasilan Rumah Sakit dalam melaksanakan tugas dan tanggung jawab pelayanan dapat dilihat dari keberhasilan dokter mendiagnosa penyakit pasien, tepat tindakan/terapi keperawatan pasien, dan tepat dalam pemberiaan dosis obat kepada pasien sebagai penunjang keberhasilan pelayanan dan penyembuhan pasien. Hal ini hendaknya ditunjang dengan pelayanan kefarmasian sebagai salah satu unsur dari pelayanan utama di rumah sakit, merupakan bagian yang tidak dapat dipisahkan dari sistem pelayanan di rumah sakit yang berorientasi kepada pelayanan pasien, penyediaan obat yang bermutu, termasuk pelayanan farmasi klinik yang terjangkau bagi semua lapisan masyarakat.

Obat merupakan komponen pembiayaan terbesar dalam satu kali rawat inap pasien, melalui strategi empat tepat (tepat diagnosa, tepat dosis, tepat obat, dan tepat pemberian) sehingga pelayanan dan keamanan pasien dalam pemberian obat 
dapat terjamin. Peranan obat bagi rumah sakit sangatlah penting, karena fungsi rumah sakit itu sendiri adalah untuk menyediakan pelayanan paripurna (komprehensif), penyembuhan penyakit (kuratif) dan pencegahan penyakit (preventif) kepada masyarakat, dan tentunya obat adalah sebagai penunjang penyembuhan penyakit, dan pencegahaan penyakit kepada pasien yang berobat. Kehabisan obat atau ketiadaan obat pada saat diperlukan dapat menyebabkan kerugian banyak pihak. Pertama Pasien tidak dapat mendapatkan pengobatan tepat waktu. Hal ini tentu berdampak pada semakin bertambah parahnya pasien yang dapat saja berakibat pada hilangnya nyawa pasien serta menurunkan kredibilitas pelayanan rumah sakit dimata pasien yang dapat saja tersebar luas. Kedua, bagi rumah sakit tentunya ketiadaan obat berdampak merugikan. Kerugian dapat saja dalam bentuk berpalingnya masyarakat ke pelayanan dari rumah sakit lain yang lebih siap dan mampu menyediakan pelayanan yang baik dan lengkap. Pada gilirannya ketiadaan obat dapat atau ketersediaan obat yang tidak tepat waktunya dapat menurunkan volume kunjungan yang berdampak pada penurunan penerimaan rumah sakit dan menurunya kinerja rumah sakit. Hal ini dapat saja terjadi pada semua rumah sakit, tidak terkecuali Rumah sakit Umum Daerah Wahab Abdul Wahab Sjahrani Samarinda.

Rumah Sakit Umum Daerah Abdoel Wahab Sjahrani Samarinda (RSU AWS) adalah sebuah rumah sakit milik Pemerintah, yang menyelenggarakan kegiatan untuk memelihara dan meningkatkan kesehatan, bertujuan untuk mewujudkan derajat kesehatan yang optimal bagi masyarakat khususnya masyarakat Kalimantan Timur. Rumah Sakit Umum Daerah Abdoel Wahab Syahrani Samarinda memiliki institusi perawatan darurat IGD yang siaga dan di jaga dokter selama 24 jam, instalasi rawat jalan biasa maupun instalasi rawat jalan paviliun, instalasi rawat inap dari kelas paviliun, kelas utama, kelas 1, kelas 2, dan kelas 3. Selain itu, Rumah Sakit Abdoel Wahab Syahrani juga memiliki fasilitas kesehatan berupa, Laboraturium PA, Laboraturium PK, Instalasi Kedokteran Nuklir, Radiologi, Radiorerapi, Instalasi Penunjang Medik, Farmasi, Medical Chek Up, Hemodialisis, Rehabilitasi Medik, Intensive Care Unit, Kamar Operasi, dan Kamar Terima Executive. 
RSU AWS Samarinda dengan unit pelayanan yang banyak baik untuk Rawat Jalan maupun rawat inap memerlukan obat yang harus selalu tersedia. Diantara berbagai jenis obat yang hendaknya disiapkan oleh rumah sakit terdapat obat generik. Beberapa jenis obat generik injeksi maupun tablet terbanyak digunakan sehingga berpotensi bahkan sering terjadi kehabisan ketika obat diperlukan secara cyto (harus segera dilakukan tindakan).

Tentu saja ketiaan obat saat cyto adalah solusi pihak farmasi menelpon dokter yang bersangkutan untuk mengkonfirmasi bahwa obat yang dibutuhkan pasien tersebut tidak tersedia, sehingga dokter harus mengganti obat yang hampir sama dengan obat yang dibutuhkan. Apabila obat yang telah diganti juga tidak tersedia, maka pihak farmasi membeli obat di apotek luar rumah sakit. Hal ini berdampak pada tertundanya pelayanan yang segera diberikan sehingga dapat berdampak bertambah parahnya sakit bahkan pasien tidak dapat tertolong nyawanya. Hal ini menunjukkan perlunya mengetahui dan menentukan jumlah obat generik yang diperlukan tersebut.

Deteksi dan penentuan jumlah obat generik yang selalu harus tersedia pada
RSU AWS Samarinda dapat dilakukan jika didukung dengan pencatatan dan penilaian persediaan secara tepat. yang berarti bahwa pencatatan dan penilaian dilakukan oleh orang yang berkompeten, berdasarkan pedoman yang sesuai. Dengan demikian perlu penelitian tentang analisis persediaan obat generik berdasarkan PSAP No 05 pada RSUD AWS Samarinda dengan reseach question berikut ini:

1. Apakah pencatatan persediaan obat generik pada RSUD Abdoel Wahab Sjahrani Samarinda sudah sesuai dengan Pernyataan Standar Akuntansi Pemerintahan (PSAP) No.05 Tahun $2010 ?$

2. Apakah penilaian persediaan obat generik di Rumah Sakit Abdoel Wahab Sjahrani Samarinda belum sesuai dengan Pernyataan Standar Akuntansi Pemerintahan (PSAP) No. 05 Tahun 2010?

\section{KERANGKA TEORITIS}

Teori yang melandasi penelitian ini adalah akuntansi sektor publik khususnya mengenai pencatatan dan penilaian persediaan berdasarkan PSAP No. 05 Tahun 2010. Banyak definisi yang diketengahkan oleh para ilmuwan. Beberapa diantaranya diuraikan berikut ini. Akuntansi sektor publik menurut 
Wiratna (2015:1) adalah aktivitas jasa yang terdiri dari mencatat, mengklasifikasikan, dan melaporkan kejadian atau transaksi ekomoni yang akhirnya akan menghasilkan suatu inormasi keuangan yanga akan dibutuhkan oleh pihak-pihak tertentu untuk mengambil keputusan, yang diterapkan pada pengelolaan dan publik di lembagalembaga tinggi negara dan departemendepartemen di bawahnya.

Akuntansi sektor publik oleh Bastian (2010:3) diartikan sebagai : Mekanisme teknis dan analisis akuntansi yang diterapkan pada pengelolaan dana masyarakat di lembaga-lembaga tinggi negara dan departemen-departemen di bawahnya, pemerintah daerah, BUMN, BUMD, LSM, dan yayasan sosial serta swasta. Mengacu pada pendapat para ilmuwan tersebut dapat disimpulkan bahwa akuntansi sektor publik merupakan suatu aktivitas jasa yang terdiri dari mencatat, mengklasifikasikan, dan melaporkan kejadian atau transaksi ekonomi yang akhirnya menghasilkan suatu informasi keuangan yang akan dibutuhkan oleh pihak-pihak tertentu untuk pengambilan keputusan yang berhubungan dengan kepentingan publik.
Menurut Bastian (2010:7):Akuntansi sektor publik mecakup bidang utama yakni: Akuntansi pemerintah pusat,Akuntansi pemerintahan daerah, Akuntansi partai politik, Akuntansi LSM, Akuntansi yayasan, Akuntansi pendidikan: sekolah, perguruan tinggi, Akuntansi kesehatan: puskesmas, rumah sakit, Akuntansi tempat peribadatan: mesjid, gereja, wihara, pura

Menurut Sujarweni (2015:3) terdapat dua bagian dalam Akuntansi Sektor Publik yaitu:

1. Akuntansi Manajemen Sektor Publik

Mempelajari bagaimana membuat informasi akuntansi yang relevan dan handal ditujukan pada pimpinan dengan maksud untuk perencanaan (perencanaan strategik, pemberian informasi biaya, penilaian investasi, dan penganggaran, penentuan biaya pelayanan, penilaian kinerja)

2. Akuntansi Keuangan Sektor Publik Mempelajari bagaimana menghasilkan transaksi-transaksi organisasi sektor publik tersebut dibukukan, sehingga akan menghasilkan laporan keuangan pada periode tertentu bagi organisasi sektor publik. 
Berdasarkan paparan kedua ilmuwan tersebut, dapat dikatakan bahwa perencanaan publik, penganggaran publik, realisasi anggaran publik, audit sektor publik, dan pertangggungjawabaan publik, merupakan bagian dari akuntansi manajemen sektor publik maupun akuntansi keuangan sektor publik, termasuk rumah sakit.

\section{Peran Akuntansi pada Rumah Sakit}

Secara operasional akuntansi manajemen di rumah sakit harus dapat menyediakan data, informasi dan petunjuk untuk membantu pimpinan rumah sakit dalam merencanakan, mengendalikan dn mengawasi seluruh kegiatan agar mutu pelayanan dapat dipertahankan atau ditingkatkan pada tingkat pembiayaan yang wajar.

Lubis (2014:3) berpendapat bahwa "Secara umum, akuntansi rumah sakit dapat didefinisikan sebagai sistem informasi yang menghasilkan laporan kepada pihak-pihak berkepentingan mengenai aktivitas ekonomi rumah sakit".

Paparan Lubis menunjukkan bahwa dari penyelenggaran akuntansi dalam rumah sakit menghasilkan informasi yang digunakan manajer untuk menyelenggarakan kegiatan rumah sakit, termasuk penentuan kebutuhan obat generik bagi pelayanan pasien.

\section{Peranan Obat pada Rumah Sakit}

Obat merupakan komponen pembiayaan terbesar dalam satu kali rawat inap, melalui strategi empat tepat (tepat diagnosa, tepat dosis, tepat obat, tepat pemberian) sehingga pelayanan dan keamanan pasien dalam pemberian obat dapat terjamin. Obat yang sering digunakan adalah obat generik.

Pengertian obat generik menurut Ernst Mustschlor hasil alih bahasa Mathilda B. Widianto dan Anna Setiadi Ranti (1999:5): Obat generik adalah obat resep yang memiliki formula bahan aktif yang sama dengan obat bermerek. Obat generik hanya dikenal dengan nama rumus dan formula yang tersedia untuk setiap perusahaan farmasi, sama aman dan efektifnya dengan obat bermerek namun biasanya lebih murah.

Pernyataan tersebut menunjukkan bahwa bahwa peranan obat bagi rumah sakit sangatlah penting, karena obat diperlukan rumah sakit untuk menyediakan pelayanan paripurna (komperhensif), penyembuhan penyakit (kuratif) dan pencegahan penyakit (preventif) kepada masyarakat, dan tentunya obat adalah sebagai penunjang 
penyembuhan penyakit, dan pencegahan penyakit kepada pasien yang berobat.

\section{Persediaan}

Libby $\quad$ (2007:336) berpendapat bahwa Persediaan merupakan aset berwujud yang dimiliki oleh perusahaan untuk dijual dalam operasi normal bisnis atau digunakan untuk menghasilkan produk atau jasa yang akan dijual. Persediaan dilaporkan dalam neraca sabagai satu aset lancar, karena biasanya persediaan digunakan atau dikonversi menjadi kas dalam waktu satu tahun atau dalam siklus operasi tahun berikutnya. Tipe persediaan akan tergantung pada karakteristik usaha. Termaktup dalam Pernyataan Standar Akuntansi Pemerintahan (PSAP) No. 05 paragraf 05 (2010:05) :

Persediaan merupakan aset yang berupa:

a. Barang atau perlengkapan (supplies) yang digunakan dalam rangka kegiatan operasional pemerintah;

b. Bahan atau perlengkapan (supplies) yang akan digunakan dalam proses produksi;

c. Barang dalam proses produksi yang dimaksudkan untuk dijual atau diserahkan kepada masyarakat; d. Barang yang disimpan untuk dijual atau diserahkan kepada masyarakat dalam rangka kegiatan pemerntahan.

\section{Sistem Pencatatan Persediaan}

Pencatatan barang-barang persediaan sangat penting dilakukan oleh suatu perusahaan untuk mencatat harga pokok suatu barang, baik itu barang yang akan dijual maupun barang yang digunakan untuk kegiatan operasional perusahaan sehari-hari. Teknik melakukan pencatatan persediaan menurut Martati, (2012:250): Dalam melakukan pencatatan persediaan, teknis pencatatan persediaan terkait juga degan sistem pencatatan yang digunakan oleh entitas. Entitas dapat menggunakan sistem periodik atau sistem perpetual. Sistem periodik merupakan sistem pencatatan persediaan dimana kuantitas persediaan ditentukan secara periodik yaitu hanya pada satu perhitungan fisik yang biasanya dilakukan secara stock opname. Sedangkan sistem perpetual merupakan sistem pencatatan persediaan dimana pencatatan yang up to date terhadap barang persediaan selalu dilakukan setiap terjadi perubahan nilai persediaan.

Menurut James (2009:348) Metode biaya persediaan dan sistem persediaan perpetual yaitu: Dalam sistem persediaan 
perpetual, seluruh kenaikan dan penurunan dalam persediaan dicatat dengan cara yang sama dengan pencatatan kenaikan dan penurunan dalam kas. Akun pesediaan pada awal periode akuntansi menunjukan persediaan tersedia pada tanggal tersebut. Pembelian dicatat dengan mendebit persediaan dan mengkredit kas atau utang usaha. Pada tanggal terjadinya penjualan, harga pokok penjualan dicatat dengan mendebit harga pokok penjuaan dan mengkredit persediaan. Merujuk pada pendapat para ilmuwan tersebut disimpulkan bahwa persediaan dapat dicatat dengan metode perpetual dan metode periodik. Pencatatan persediaan dengan sistem perpetual dilakukan setiap terjadi transaksi barang masuk dan barang keluar dan pada akhir periode dilakukan perhitungan secara fisik, sedangkan pencatatan persediaan dengan metode periodik hanya melakukan pencatatan persediaan ada saat akhir periode dengan melakukan perhitungan fisik barang tanpa mencatat keluar masuknya barang tersebut.

\section{Metode Penilaian Persediaan}

Secara teoritis seharusnya suatu entitas menggunakan harga yang spesifik yang terkait dengan barang yang ditentukan biaya persediaannya. Namun, sering kali hal ini sulit dilakukan karena suatu entitas melakukan pembelian dalam frekuensi dan jumlah yang tinggi dan barang tersebut merupakan barang mass product (produksi masal) yang sulit diidentifikasikan secara khusus dan dapat saling menggantikan satu sama lain. Oleh karena itu, suatu entitas menggunakan asumsi arus biaya dalam mengukur biaya persediaan. Metode penilaian persediaan menurut Libby (2009:224): Dalam satu periode, entitas biasanya melakukan beberapa kali pembelian pada waktu yang berbeda dan kemungkinan besar harganya sudah berbeda. Apabila terdapat beberapa pembelian dengan biaya per unit persediaan, maka terdapat empat macam metode yang diperkenankan untuk digunakan, yaitu identifikasi khusus, First In First Out (FIFO), Last In First Out (LIFO), dan rata-rata tertimbang.

\section{Dampak Kesalahan Pencatatan}

\section{Persediaan}

Kesalahan pencatatan persediaan berdampak pada kesalahan penetapan beban pokok penjualan dan pada akhirnya menyebabkan kesalahan pada laporan keuangan. Jika persediaan akhir dilaporkan terlalu rendah, maka beban pokok penjualan menjadi terlalu tinggi dan pada akhirnya menyebabkan laba bersih 
menjadi terlalu rendah. Menurut Herry (2018:238), dampak kesalahan pencatatan persediaan adalah: Kesalahan dalam mencatat besarnya fisik persediaan ini akan menyebabkan salah saji dalam saldo persediaan akhir. Karena persediaan merupakan aset lancar, maka besarnya aset lancar maupun total aset perusahaan secara keseluruhan juga akan menjadi salah saji di neraca. Kesalahan dalam melakukan perhitungan atas persediaan ini juga akan mengakibatkan besarnya harga pokok penjualan, laba kotor, dan laba bersih yang tersaji dalam laporan laba rugi menjadi keliru.

\section{Pernyataan Standar Akuntansi Pemerintahan No. 05 Tentang Persediaan.}

Pernyataan Standar Akuntansi Pemerintahan (PSAP) No. 05 Tahun 2010 tentang persediaan merupakan pedoman atau acuan dalam suatu entitas pemerintahan untuk mengatur proses persediaan secara efektif dan efesien. Berikut penjelasan dari Pernyataan Standar Akuntansi Pemerintahan (PSAP) No. 05 Tahun 2010 tentang persediaan.

Ruang lingkup pada Pernyataan Standar Akuntansi Pemerintahan No.05 Tahun 2010 (2018:163): Pernyataan Standar ini terapkan dalam penyajian seluruh persediaan dalam laporan keuangan untuk tujuan umum. Standar ini diterapkan untuk seluruh entitas pemerintahan pusat dan daerah tidak termasuk perusahaan negara/daerah. Pernyataan Standar ini tidak mengatur:

a. Persediaan bahan baku dan perlengkapan yang dimiliki proyek swakelola dan dibebankan ke suatu akun konstruksi dalam pengerjaan; dan

b. Instrumen keuangan.

\section{Hipotesis}

Hipotesis pada penelitian ini adalah:

1. Pencatatan persediaan obat generik pada RSUD Abdoel Wahab Sjahranni Samarinda belum sesuai dengan Pernyataan Standar Akuntansi Pemerintahan (PSAP) No. 05 Tahun 2010.

2. Penilaian persediaan obat generik pada RSUD Abdoel Wahab Sjahranni Samarinda belum sesuai dengan Pernyataan Standar Akuntansi Pemerintahan (PSAP) No. 05 Tahun 2010.

\section{METODE PENELITIAN}

\section{Definisi Operasional}

Penelitian ini difokuskan pada pencatatan dan penilaian persediaan obat generik yang penggunaannya terbanyak dan sering terjadi kehabisan persediaan, 
maka perlu dioperasionalkan beberapa pengertian berikut ini:

Persediaan adalah 5 jenis obat generik injeksi dan 5 jenis obat generik tablet, yaitu $\mathrm{NaCl} \quad 0,9 \% \quad 500 \mathrm{Ml}$ Inj, Ranitidin Inj, Dexamethasone 5 Ml Inj, Cefotaxime 1 g Inj, Gentamicin $80 \mathrm{Mg}$ Inj, Amoxicillin $500 \mathrm{Mg}$, Antasida Doen, Dexamethasone 0,5 Mg, Chlorpeniramin, dan Lansoprazol yang digunakan pada Rumah Sakit Umum Daerah Abdoel Wahab Sjahranie Samarinda.

Pencatatan persediaan adalah membukukan 5jenis obat generik injeksi maupun obat generik tablet setiap terjadi mutasi penerimaan, pengeluaran obat maupun saldo obat generik pada RSUD Abdoel Wahab Sjahrani. Pencatatan persediaan dengan menggunakan metode perpetual yaitu mencatat setiap terjadi mutasi penambahan, pengeluaran,maupun saldo dari lima jenis obat generik injeksi dan lima obat generik tablet .

Penilaian persediaan adalah cara RSUD Abdoel Wahab Sjahrani Samarinda menentukan atau menilai obat generik injeksi dan obat generik tablet.Penilaian persediaan dengan metode $\mathrm{FIFO(First} \mathrm{In}$
First Out) yaitu penilaian persediaan didasarkan atas asumsi bahwa harga barang persediaan yang sudah terjual atau dipakai dinilai menurut harga pembelian barang yang terdahulu masuk, persediaan akhir dinilai menurut harga pembelian barang yang terakhir masuk.

\section{Teknik Pengumpulan Data}

Pengumpulan data dilakukan dengan wawancara dan studi dokumentasi untuk memperoleh data dan informasi tentang kartu stok opname

obat generik, dan kartu persediaan FIFO obat generik RSUD Abdoel Wahab Sjahranie Samarinda.

\section{Metode Analisis}

Metode analisis yang digunakan yaitu analisis deskriptif komparatif, yaitu membandingkan pencatatan dan penilaian persediaan dengan menggunakan sampel obat generik yang dilakukan RSUD Abdoel Wahab Sjahranie Samarinda dengan Pernyataan Standar Akuntansi Pemerintahan (PSAP) No. 05 Tahun 2010 tentang persediaan. Prosedur analisis sebagai berikut: 1. Pencatatan persediaan dengamenggunakan metode perpetual

\section{Tabel 1 Jurnal Persediaan Metode Pencatatan Perpetual}

\begin{tabular}{llll}
\hline Tanggal & Keterangan & Debet & Kredit \\
\hline \multirow{2}{*}{ Persediaan awal } & Ikhtisar laba/rugi & xxx & \\
\cline { 2 - 4 } & Persediaan barang & & xxx \\
\cline { 2 - 4 } & & &
\end{tabular}




\begin{tabular}{|c|c|c|c|}
\hline \multirow{2}{*}{$\begin{array}{c}\text { Pembelian barang } \\
\text { dagangan tunai/kredit }\end{array}$} & Persediaan barang dagang & \multicolumn{2}{|l|}{$\mathrm{xxx}$} \\
\hline & Kas/Utang dagang & & $\mathrm{xxX}$ \\
\hline \multirow{2}{*}{ Retur Pembelian } & Kas & $\mathrm{xxx}$ & \\
\hline & Persediaan barang dagang & & $\mathrm{xxx}$ \\
\hline \multirow{2}{*}{ Potongan pembelian } & Kas & $\mathrm{xxx}$ & \\
\hline & Persediaan barang dagang & & $\mathrm{xxx}$ \\
\hline \multirow{2}{*}{ Beban angkut pembelian } & Persediaan barang dagang & $\mathrm{xxx}$ & \\
\hline & Kas/Utang dagang & & $\mathrm{xxx}$ \\
\hline \multirow{4}{*}{ Penjualan tunai/kredit } & Kas/Piutang & $\mathrm{XxX}$ & \\
\hline & Penjualan & & $\mathrm{xxx}$ \\
\hline & Harga pokok penjualan & $\mathrm{xxx}$ & \\
\hline & Persediaan barang dagang & & $\mathrm{XXX}$ \\
\hline \multirow{4}{*}{ Retur penjualan } & Retur penjualan & $\mathrm{xxx}$ & \\
\hline & Kas/Piutang dagang & & $\mathrm{XXX}$ \\
\hline & Persediaan barang dagang & $\mathrm{xxx}$ & \\
\hline & Harga pokok penjualan & & $\mathrm{xxx}$ \\
\hline \multirow{2}{*}{ Potongan penjualan } & Potongan penjualan & $\mathrm{xxx}$ & \\
\hline & Kas & & $\mathrm{xxx}$ \\
\hline \multirow{2}{*}{ Beban angkut penjualan } & Beban angkut penjualan & $\mathrm{XxX}$ & \\
\hline & Kas & & $\mathrm{xxx}$ \\
\hline \multirow{2}{*}{ Laba Penjualan } & Penjualan & $\mathrm{xxx}$ & \\
\hline & Persediaan barang & & $\mathrm{xxx}$ \\
\hline \multirow{2}{*}{ Persediaan akhir } & Persediaan barang & $\mathrm{xxx}$ & \\
\hline & Ikhtisar laba/rugi & & $\mathrm{xxX}$ \\
\hline
\end{tabular}

Sumber: Anastasia (2017:188)

2. Metode Penilaian First In First Out (FIFO)

Menurut Anastasia (2012: 188)

"Formula FIFO mengasumsikan unit persediaan yang pertama dibeli akan dijual (digunakan) terlebih dahulu sehingga unit yang tertinggal dalam persediaan akhir adalah yang dibeli (diproduksi) kemudian".

Tabel 2 Kartu Persediaan FIFO

\begin{tabular}{|c|c|c|c|c|c|c|c|c|c|}
\hline \multicolumn{10}{|c|}{ Nama Barang: } \\
\hline \multicolumn{4}{|c|}{ Pembelian } & \multicolumn{3}{|c|}{ Penggunaan/Penjualan } & \multicolumn{3}{|c|}{ Saldo } \\
\hline Tanggal & Kuantitas & $\begin{array}{c}\text { Biaya } \\
\text { Per } \\
\text { Unit }\end{array}$ & $\begin{array}{c}\text { Jumlah } \\
\text { Biaya }\end{array}$ & Kuantitas & $\begin{array}{c}\text { Biaya } \\
\text { Per } \\
\text { Unit }\end{array}$ & $\begin{array}{c}\text { Jumlah } \\
\text { Biaya }\end{array}$ & Kuantitas & $\begin{array}{c}\text { Biaya } \\
\text { Per } \\
\text { Unit }\end{array}$ & $\begin{array}{c}\text { Jumlah } \\
\text { Biaya }\end{array}$ \\
\hline
\end{tabular}

Sumber: James (2009:349)

\section{HASIL PENELITIAN}

\section{Analisis}

Semua obat generik dicatat oleh RSUD AWS Samarinda pada kartu stok obat dengan model yang tertera pada tabel 3.1. Terdapat lima jenis obat generik injeksi dan 5 jenis obat generik tablet yaitu $\mathrm{NaCl}$ 0,9\% 500 Ml Inj, Ranitidin Inj, Dexamethasone $5 \mathrm{Ml} \mathrm{Inj,}$ 
Cefotaxime $1 \mathrm{~g}$ Inj, Gentamicin $80 \mathrm{Mg}$ Inj, dan Lansoprazol. Pada bagian ini Amoxicillin $500 \mathrm{Mg}$, Antasida Doen, ditampilkan kartu stok $\mathrm{NaCl}$ 0,9\% $500 \mathrm{Ml}$ Dexamethasone 0,5 Mg, Chlorpeniramin, Inj pada bulan Januari.

Tabel 3 Kartu Stok NaCl 0,9\% 500 Ml Tahun 2018

\begin{tabular}{|c|c|c|c|c|c|c|}
\hline \multicolumn{7}{|c|}{ Nama Barang: NaCl 0,9\% 500 Ml Inj } \\
\hline Tanggal & Masuk & Keluar & Sisa & & Total Sisa & Ket \\
\hline & & & & \multicolumn{3}{|c|}{28.525} \\
\hline & & 40 & & 28485 & & AWS.D \\
\hline & & 300 & & 28185 & & OK.IBS \\
\hline & & 100 & & 28085 & & Ok.Sakura \\
\hline & & 500 & & 27.585 & & IGD \\
\hline & & 300 & & 27.285 & & OK.IBS \\
\hline & & 20 & & 27.265 & & R.INAP \\
\hline & & 40 & & 27.225 & & AWS.D \\
\hline & & 3.200 & & 24.025 & & R.INAP \\
\hline & & 120 & & 23.905 & & BHP \\
\hline & & 1.600 & & 22.305 & & R.INAP \\
\hline & & 300 & & 22.005 & & OK.IBS \\
\hline & & 200 & & 21.805 & & TERATAI \\
\hline & & 1.000 & & 20.805 & & IGD \\
\hline & & 500 & & 20.305 & & OK.IGD \\
\hline & & 1.600 & & 18.705 & & R.INAP \\
\hline & & 1.600 & & 17.105 & & R.INAP \\
\hline & & 2.000 & & 15.105 & & BHP \\
\hline & & 300 & & 14.805 & & OK.IBS \\
\hline
\end{tabular}

Sumber : RSUD AWS,2019

\section{Tabel 4 Kartu Persediaan FIFO}

\begin{tabular}{|c|c|c|c|c|c|c|c|c|c|c|}
\hline \multicolumn{11}{|c|}{ Nama Barang: $\mathrm{NaCl}$ 0,9\% $500 \mathrm{Ml}$ Inj } \\
\hline \multirow[t]{3}{*}{ Tanggal } & \multicolumn{3}{|c|}{ Pembelian } & \multicolumn{3}{|c|}{ Penggunaan/Penjualan } & \multicolumn{3}{|c|}{ Saldo } & \multirow[t]{2}{*}{ Ket } \\
\hline & $\begin{array}{l}\text { Kuantit } \\
\text { as }\end{array}$ & $\begin{array}{c}\text { Biaya/U } \\
\text { nit }\end{array}$ & $\begin{array}{c}\text { Jumlah } \\
\text { Biaya }\end{array}$ & $\begin{array}{c}\text { Kuantit } \\
\text { as }\end{array}$ & $\begin{array}{c}\text { Biaya/U } \\
\text { nit }\end{array}$ & $\begin{array}{c}\text { Jumlah } \\
\text { Biaya }\end{array}$ & $\begin{array}{c}\text { Kuantit } \\
\text { as }\end{array}$ & $\begin{array}{c}\text { Biaya/U } \\
\text { nit }\end{array}$ & $\begin{array}{c}\text { Jumlah } \\
\text { Biaya }\end{array}$ & \\
\hline & (unit) & (Rp) & $(\mathbf{R p})$ & (unit) & $(\mathbf{R p})$ & (Rp) & (unit) & $(\mathbf{R p})$ & (Rp) & \\
\hline $01 / 01 / 20$ & & & & & & & & & 182.845 .25 & \\
\hline 18 & & & & & & & 28.525 & 6.410 & 0 & \\
\hline $05 / 01 / 20$ & & & & & & & & & 182.588 .85 & \\
\hline 18 & & & & 40 & 6.410 & 256.400 & 28485 & 6.410 & 0 & AWS.D \\
\hline $05 / 01 / 20$ & & & & & & & & & 180.665 .85 & \\
\hline 18 & & & & 300 & 6.410 & 1.923 .000 & 28185 & 6.410 & 0 & OK.IBS \\
\hline $05 / 01 / 20$ & & & & & & & & & 180.024 .85 & Ok.Sak \\
\hline 18 & & & & 100 & 6.410 & 641.000 & 28085 & 6.410 & 0 & ura \\
\hline $10 / 01 / 20$ & & & & & & & & & 176.819 .85 & \\
\hline 18 & & & & 500 & 6.410 & 205.000 & 27.585 & 6.410 & 0 & IGD \\
\hline $10 / 01 / 20$ & & & & & & & & & 174.896 .85 & \\
\hline 18 & & & & 300 & 6.410 & 1.923 .000 & 27.285 & 6.410 & 0 & OK.IBS \\
\hline $10 / 01 / 20$ & & & & & & & & & 174.768 .65 & \\
\hline 18 & & & & 20 & 6.410 & 128.200 & 27.265 & 6.410 & 0 & R.INAP \\
\hline $11 / 01 / 20$ & & & & & & & & & 174.512 .25 & \\
\hline 18 & & & & 40 & 6.410 & 256.400 & 27.225 & 6.410 & 0 & AWS.D \\
\hline $12 / 01 / 20$ & & & & & & & & & & \\
\hline 18 & & & & 3.200 & 6.410 & 20.512 .000 & 24.025 & 6.410 & 15.400 .250 & R.INAP \\
\hline $18 / 01 / 20$ & & & & & & & & & 153.231 .05 & \\
\hline 18 & & & & 120 & 6.410 & 769.200 & 23.905 & 6.410 & 0 & BHP \\
\hline $19 / 01 / 20$ & & & & 1.600 & 6.410 & 10.256 .000 & 22.305 & 6.410 & 142.975 .05 & R.INAP \\
\hline
\end{tabular}




\begin{tabular}{|c|c|c|c|c|c|c|c|}
\hline 18 & & & & & \multicolumn{3}{|c|}{0} \\
\hline $22 / 01 / 20$ & & & & & \multicolumn{3}{|c|}{141.052 .05} \\
\hline 18 & 300 & 6.410 & 1.923 .000 & 22.005 & 6.410 & 0 & OK.IBS \\
\hline $22 / 01 / 20$ & & & & & & 139.770 .05 & TERAT \\
\hline 18 & 200 & 6.410 & 1.282 .000 & 21.805 & 6.410 & 0 & AI \\
\hline $23 / 01 / 20$ & & & & & & 133.360 .05 & \\
\hline 18 & 1.000 & 6.410 & 6.410 .000 & 20.805 & 6.410 & 0 & IGD \\
\hline $24 / 01 / 20$ & & & & & & 130.155 .05 & OK.IG \\
\hline 18 & 500 & 6.410 & 3.205 .000 & 20.305 & 6.410 & 0 & $\mathrm{D}$ \\
\hline $26 / 01 / 20$ & & & & & & 119.899 .05 & \\
\hline 18 & 1.600 & 6.410 & 10.256 .000 & 18.705 & 6.410 & 0 & R.INAP \\
\hline $31 / 01 / 20$ & & & & & & 109.643 .05 & \\
\hline 18 & 1.600 & 6.410 & 10.256 .000 & 17.105 & 6.410 & 0 & R.INAP \\
\hline $31 / 01 / 20$ & & & & & & & \\
\hline 18 & 2.000 & 6.410 & 12.820 .000 & 15.105 & 6.410 & 96.823 .050 & BHP \\
\hline $31 / 01 / 20$ & & & & & & & \\
\hline 18 & 300 & 6.410 & 1.923 .000 & 14.805 & 6.410 & 94.900 .050 & OK.IBS \\
\hline
\end{tabular}

\section{Sumber : Data Diolah,2018}

Seterusnya Kartu persediaan FIFO obat generik tablet. Hasil perhitungan dari dibuat sampai dengan bulan Desember 2018 kartu persediaan dijadikan dasar dalam untuk setiap obat generik injeksi maupun pencatatan dan penilaian persediaan.

Tabel 6 Jurnal Persediaan Perpetual NaCl 0,9\% / 500 Ml Inj Periode 2018

\begin{tabular}{|c|c|c|c|c|}
\hline Tanggal & & Keterangan & Debet $(\mathrm{Rp})$ & Kredit (Rp) \\
\hline \multirow{2}{*}{$01 / 01 / 2018$} & \multirow{2}{*}{$\begin{array}{c}\text { Persediaan } \\
\text { Awal }\end{array}$} & Ikhtisar laba rugi & 182.845 .250 & \\
\hline & & Persediaan barang & & 182.845 .250 \\
\hline \multirow{4}{*}{$05 / 01 / 2018$} & \multirow{4}{*}{$\begin{array}{l}\text { Penjualan } \\
\text { Tunai }\end{array}$} & Kas & 320.500 & \\
\hline & & Penjualan & & 320.500 \\
\hline & & Harga pokok penjualan & 256.400 & \\
\hline & & Persediaan barang & & 256.400 \\
\hline \multirow{4}{*}{$05 / 01 / 2018$} & \multirow{4}{*}{$\begin{array}{l}\text { Penjualan } \\
\text { Tunai }\end{array}$} & Kas & 2.403 .750 & \\
\hline & & Penjualan & & 2.403 .750 \\
\hline & & Harga pokok penjualan & 1.923 .000 & \\
\hline & & Persediaan barang & & 1.923 .000 \\
\hline \multirow{4}{*}{$05 / 01 / 2018$} & \multirow{4}{*}{$\begin{array}{l}\text { Penjualan } \\
\text { Tunai }\end{array}$} & Kas & 801.250 & \\
\hline & & Penjualan & & 801.250 \\
\hline & & Harga pokok penjualan & 641.000 & \\
\hline & & Persediaan barang & & 641.000 \\
\hline \multirow{4}{*}{$10 / 01 / 2018$} & \multirow{4}{*}{$\begin{array}{l}\text { Penjualan } \\
\text { Tunai }\end{array}$} & Kas & 4.006 .250 & \\
\hline & & Penjualan & & 4.006 .250 \\
\hline & & Harga pokok penjualan & 3.205 .000 & \\
\hline & & Persediaan barang & & 3.205 .000 \\
\hline \multirow{4}{*}{$10 / 01 / 2018$} & \multirow{4}{*}{$\begin{array}{l}\text { Penjualan } \\
\text { Tunai }\end{array}$} & Kas & 2.403 .750 & \\
\hline & & Penjualan & & 2.403 .750 \\
\hline & & Harga pokok penjualan & 1.923 .000 & \\
\hline & & Persediaan barang & & 1.923 .000 \\
\hline \multirow{3}{*}{$10 / 01 / 2018$} & \multirow{3}{*}{$\begin{array}{c}\text { Penjualan } \\
\text { Tunai }\end{array}$} & Kas & 160.250 & \\
\hline & & Penjualan & & 160.250 \\
\hline & & Harga pokok penjualan & 128.200 & \\
\hline
\end{tabular}




\begin{tabular}{|c|c|c|c|c|}
\hline & & Persediaan barang & & 128.200 \\
\hline \multirow{4}{*}{$10 / 01 / 2018$} & \multirow{4}{*}{$\begin{array}{l}\text { Penjualan } \\
\text { Tunai }\end{array}$} & Kas & 320.500 & \\
\hline & & Penjualan & & 320.500 \\
\hline & & Harga pokok penjualan & 256.400 & \\
\hline & & Persediaan barang & & 256.400 \\
\hline \multirow{4}{*}{$12 / 01 / 2018$} & \multirow{4}{*}{$\begin{array}{l}\text { Penjualan } \\
\text { Tunai }\end{array}$} & Kas & 25.640 .000 & \\
\hline & & Penjualan & & 25.640 .000 \\
\hline & & Harga pokok penjualan & 20.512 .000 & \\
\hline & & Persediaan barang & & 20.512 .000 \\
\hline .............. & ....... & .................. & ............ & .................. \\
\hline \multirow[t]{4}{*}{$31 / 01 / 2018$} & $\begin{array}{l}\text { Penjualan } \\
\text { Tunai }\end{array}$ & Kas & 16.25 .000 & \\
\hline & & Penjualan & & 16.025 .000 \\
\hline & & Harga pokok penjualan & 12.820 .000 & \\
\hline & & Persediaan barang & & 12.820 .000 \\
\hline
\end{tabular}

\section{Sumber : Data Diolah,2018}

Pencatatan obat generik injeksi Ranitidin Inj, Dexamethasone 5 Ml Inj,Cefotaxime 1 g Inj, Gentamicin $80 \mathrm{Mg}$ Inj, dan pencatatan obat generik Amoxicillin 500 Mg, Antasida Doen, Dexamethasone 0,5 $\mathrm{Mg}$, Chlorpeniramin, dan Lansoprazol

\section{Obat Generik}

dilakukan dengan cara yang sama

Hasil pencatatan dan penilaian persediaan 10 jenis obat generik tersebut berdasarkan ketentuan PSAP No 05 Tahun 2010, diperoleh nilai persediaan akhir pada tahun 2018 sebagai berikut:

\begin{tabular}{lr}
\hline $\mathrm{Na}$ Cl 0,9\% 500Ml Inj & 58.202 .800 \\
\hline Ranitidin Inj & - \\
\hline Dexamethasone 5 Ml Inj & 7.392 .760 \\
\hline Cefatoxime 1 g Inj & 4.752 .000 \\
\hline Gentamicin $80 \mathrm{Mg}$ Inj & 6.701 .120 \\
\hline Amoxicillin 500Mg & 1.439 .800 \\
\hline Antasida Doen & 263.500 \\
\hline Dexamethasone 0,5 Mg & 180.200 \\
\hline Chlorpeniranim & 517.500 \\
\hline Lansoprazol & 3.650 .400 \\
\hline
\end{tabular}

Sumber : Data Diolah, 2019

Merujuk pada pencatatan dan penilaian persediaan berdasarkan PSAP No 05 Tahun 2010 dimana pencatatan persediaan dengan metode perpetual dan penilaian persediaan dengan menggunakan metode FIFO dan pencatatan dan penilaian persediaan yang dilakukan RSUD AWS Samarinda dilakukan perbandingan sebagaimana tampak pada tabel 7. 
Tabel 7 Perbandingan Menurut PSAP No. 05 Tahun 2010 dengan RSUD AWS Samarinda

\begin{tabular}{llll}
\hline Uraian & Menurut & Menurut & Keterangan \\
\hline & PSAP No & RSUD & $\begin{array}{l}\text { (Sesuai/Belum } \\
\text { sesuai }\end{array}$ \\
& 05 & AWS & Belum Sesuai \\
\hline Pencatatan Persediaan & Perpetual & Famarinda & Selisih) \\
\hline Penilaian Persediaan & FIFO & FIFO & Relum Sesuai \\
\hline & \multicolumn{3}{c}{ Rata-Rata } \\
\hline
\end{tabular}

Persediaan Akhir Obat Generik (

$\mathrm{Rp})$ :

Selisih

\begin{tabular}{lrrr}
\hline Na Cl 0,9\% 500Ml Inj & 58.202 .800 & 111.630 .150 & 53.427 .350 \\
\hline Ranitidin Inj & - & 779.625 & 779.625 \\
\hline Dexamethasone 5 Ml Inj & 7.392 .760 & 18.633 .324 & 11.240 .564 \\
\hline Cefatoxime 1 g Inj & 4.752 .000 & 21.615 .000 & 16.863 .000 \\
\hline Gentamicin 80 Mg Inj & 6.701 .120 & 10.117 .912 & 3.416 .792 \\
\hline Amoxicillin 500Mg & 1.439 .800 & 1.846 .819 & 407.019 \\
\hline Antasida Doen & 263.500 & 539.400 & 275.900 \\
\hline Dexamethasone 0,5 Mg & 180.200 & 301.818 & 121.618 \\
\hline Chlorpeniranim & 517.500 & 329.304 & 188.196 \\
\hline Lansoprazol & 3.650 .400 & 4.120 .920 & 470.520 \\
\hline Sumber: Data diolah,
\end{tabular}

Sumber: Data diolah, 2019

\section{Pembahasan}

Pencatatan persediaan obat generik yang seharusnya dilakukan berdasarkan metode perpetual sebagaimanan diatur dalam PSAP No. 05 Tahun 2010 belum diterapkan sepenuhnya oleh RSUD Abdoel Wahab Sjahranie Samarinda. Pencatatan persediaan obat generik RSUD Abdoel Wahab Sjahranie Samarinda adalah metode pencatatan secara fisik berdasarkan kartu stok obat dan perhitungan fisik di akhir periode, tidak ada pencatatan seperti penjurnalan secara perpetual ataupun penjurnalan secara periodik. Temuan ini membuktikan hipotesis bahwa Pencatatan persediaan obat generik pada RSUD Abdoel Wahab Sjahranni Samarinda belum sesuai dengan Pernyataan Standar Akuntansi Pemerintahan (PSAP) No. 05 Tahun 2010. Penilaian persediaan obat generik menurut PSAP No. 05 Tahun 2010 menggunakan metode FIFO, sedangkan RSUD Abdoel Wahab Sjahranie Samarinda menggunakan metode FIFO dan rata-rata tertimbang. Akibat dari perbedaan penilaian persediaan obat generik ini, maka terjadi perbedaan penilaian persediaan akhir obat generik sebagaimana tampak pada tabel 7 . Perbedaan tersebut menimbulkan selisih nilai persediaan $\mathrm{Na} \mathrm{Cl} 0,9 \%$ 500Ml Inj 
Research Journal of Accounting and Business Management (RJABM); P-ISSN: 2580-3115; E-ISSN: 2580-3131

sebesar Rp 53.427.350(dicatat lebih banyak jumlahnya oleh RSUD AWS Samarinda). Demikian pula terjadi selisih nilai persediaan akhir Ranitidin Inj sebesar Rp779.625 (dicatat lebih banyak jumlahnya oleh RSUD AWS Samarinda). Terjadi pula selisih nilai persediaan akhir Dexamethasone $5 \mathrm{Mg} / \mathrm{Ml}$ Inj sebesar Rp11.240.564(dicatat lebih banyak jumlahnya oleh RSUD AWS Samarinda). Selisih nilai persediaan akhir Cefotaxime 1 g Inj sebesar Rp16.863.000( dicatat lebih banyak jumlahnya oleh RSUD AWS Samarinda). Selisih nilai persediaan akhir Gentamicin $80 \quad \mathrm{Mg} \quad \mathrm{Inj}$ sebesar Rp3.416.792(dicatat lebih banyak jumlahnya oleh RSUD AWS Samarinda). Selisih nilai persediaan akhir Amoxicillin $500 \mathrm{Mg}$ menurut PSAP No. 05 Tahun 2010 sebesar Rp407.019(dinilai lebih banyak jumlahnya oleh RSUD AWS Samarinda). Selisih nilai persediaan akhir Antasida Doen sebesar Rp275.900(dinilai lebih banyak jumlahnya oleh RSUD AWS Samarinda). Demikian pula terjadi selisih nilai persediaan akhir Dexamethasone 0,5 $\mathrm{Mg}$ (dicatat lebih banyak jumlahnya oleh RSUD AWS Samarinda Rp121.618). Selanjutnya terjadi selisih nilai persediaan akhir Chlorpeniramin Rp188.196(dinilai lebih sedikit jumlahnya oleh RSUD AWS Samarinda) karena perhitungan menurut PSAP No. 05 Tahun 2010 sebesar Rp517.500, sedangkan menurut RSUD
Abdoel Wahab Sjahranie Samarinda sebesar Rp329.304. Selisih nilai persediaan akhir Lansoprazol sebesar Rp470.520(dicatat lebih banyak jumlahnya oleh RSUD AWS Samarinda). Penilaian persediaan obat generik pada RSUD Abdoel Wahab Sjahranie Samarinda belum sesuai dengan PSAP No. 05 Tahun 2010. Meskipun di sistemnya pihak rumah sakit menggunakan metode FIFO, tetapi secara nyata di gudang farmasi RSUD Abdoel Wahab Sjahranie Samarinda belum menggunakan metode FIFO melainkan menggunakan metode rata-rata tertimbang, tetapi dari hasil penelitian tidak terdapat bukti tertulis tentang penilaian persediaan obat generik dengan metode rata-rata tertimbang, hanya saja dari hasil wawancara dengan salah satu karyawan gudang farmasi RSUD Abdoel Wahab Sjahranie Samarinda menyatakan bahwa penilaian persediaan yang dilakukan oleh pihak gudang farmasi dengan menggunakan metode rata-rata tertimbang. Selain itu, di sistemnya RSUD Abdoel Wahab Sjahranie Samarinda menggunakan metode FIFO dalam menilai persediaan obat-obatannya, tetapi RSUD Abdoel Wahab Sjahranie Samarinda tidak menghitung penilaian persediaan obatobatan sesuai dengan keluar masuknya transaksi melainkan hanya menghitung FIFO transaksi setiap bulan saja. Temuan ini mendukung hipotesis penelitian. 
Hasil selisih nilai persediaan dikategorikan menjadi dua kategori yaitu selisih lebih dan selisih kurang yang samasama berdampak merugikan. Bila dilihat dari RSUD AWS Samarinda obat generik NaCL0,9\% Ml Inj, Ranitidin Inj, Dexamethasone $5 \mathrm{Ml}$ Inj,Cefotaxime $1 \mathrm{~g}$ Inj, Gentamicin $80 \mathrm{Mg}$ Inj, Amoxicillin $500 \mathrm{Mg}$, Antasida Doen, Dexamethasone $0,5 \mathrm{Mg}$ dan Lansoprazol dinilai terlalu besar atau diakui masih tersedia banyak bahkan obat generik Ranitidin Inj dinilai masih tersedia ternyata menurut penilaian FIFO perpetual nol rupiah. Hal ini tentu saja menjadi pengganggu dalam pelayanan medis pada RSUD AWS Samarinda karena obat-obat generik tersebut dinilai masih banyak tersedia yang jika dibiarkan terus berlanjut, maka pada suatu waktu akan habis tanpa diketahui sebelumnya dimana dapat mengakibatkan pelayanan pasien tertunda dan sangat membahayakan pelayanan cyto. Sebaliknya obat generik Chlorpeniramin dinilai kurang sementara tersedia dalam jumlah yang cukup. Hal ini juga berdampak merugikan karena obat dapat menjadi kadaluarsa dan terjadi pemborosan modal yang digunakan untuk obat.

\section{KESIMPULAN DAN SARAN}

\section{Kesimpulan}

Pencatatan dan penilaian persediaan obat generik pada RSUD AWS Samarinda sangat penting dilakukan secara tepat.
Tepat yang dimaksudkan disini adalah tepat orang yang melakukan pencatatan maupun penilaian dan tepat metode yang digunakan. Metode pencatatan dan penilaian persediaan yang tepat bagi RSUD AWS Samarinda sebagai perusahaan milik pemerintah adalah merujuk pada ketentuan PSAP no 5 Tahun 2010.

\section{Saran}

Ketepatan pencatatan dan penilaian persediaan obat mutlak perlu dilakukan karena kekurangan dan atau ketiadaan persediaan obat dapat berdampak fatal bagi pasien maupun Rumah Sakit. Demikian pula jika terjadi kelebihan persediaan obat berdampak merugikan karena obat yang tersimpan dalam jumlah banyak dapat menjadi kadaluarsa dan menimbulkan pemborosan. Adanya pencatatan dan penilaian persediaan yang tepat, dapat diketahui jumlah persediaan obat yang sebenarnya sehingga dapat dijadikan dasar dalam pengambilan keputusan mengenai persediaan obat.

\section{DAFTAR PUSTAKA}

Bastian, Indra. 2010. Akuntansi Sektor Publik: Suatu Pengantar. Jakarta Erlangga.

Diana, Anastasia., Setiawati, Lilis. 2017. Akuntansi Keuangan Menengah Berdasarkan Akuntansi Keuangan Terbaru. Yogyakarta: CV. Andi Offset 
Harrison, Walter T. 2012. Akuntansi Keuangan International Financial Reporting Standards-IFRS. Jakarta: Erlangga

Libby, Robert, Patricia A. Libby, Daniel G. Short.. 2007. Akuntansi keuangan. Yogyakarta: Andi

Lubis, Arfan Ikhsan dan Ida Bagus Agung Dharmanegara. 2014. Akuntansi dan Manajemen Keuangan Rumah Sakit. Yogyakarta: Graha Ilmu

Martani, Dwi. et, al. 2012. Akuntansi Keuangan Menengah Berbasis
PSAK. Jakarta: Salemba Empat

Nitzki, Diane dan George. 2004. Generic Alternatives To Prescription Drugs, Your Giunde to Buying Effective Drugs at Cost-Saving Prices. Amerika..

Reeve, James M. et, al. 2009. Principles of Accounting-Indonesia Adaptation. Jakarta: Salemba Empat.

Sujarweni, V. Wiratna. 2015. Akuntansi Sektor Publik. Yogyakarta: Pustaka Baru

Press. 